\title{
ANALISIS KANDUNGAN SIBUTRAMIN HIDROKLORIDA PADA PRODUK HERBAL PELANGSING DENGAN METODE SPEKTROFOTOMETRI UV-VIS
}

\section{ANALYSIS OF SIBUTRAMINE HYDROCHLORIDE IN SLIMMING HERBS PRODUCT BY UV-VIS SPECTROPHOTOMETRY METHOD}

\author{
Nadya Novani' ${ }^{1}$, Andika ${ }^{2}$, Hayatus Sa'adah $^{3}$ \\ ${ }^{123}$ Program Studi S1 Farmasi, Fakultas Farmasi, Universitas Muhammadiyah Banjarmasin \\ Jl. Gubernur Sarkawi, Handil Bakti, Kalimantan Selatan \\ Email:nadyanovani999@gmail.com
}

Submitted : 09 Juli 2021 Reviewed : 26 Agustus 2021 Accepted : 20 September 2021

\begin{abstract}
ABSTRAK
Produk herbal dilarang mengandung bahan kimia obat. Bahan kimia obat pada beberapa penelitian masih terkandung dalam produk herbal. Sibutramin Hidroklorida adalah bahan kimia obat yang paling banyak terindentifikasi pada produk herbal pelangsing. Tujuan dari penelitian ini untuk mengetahui kandungan dan kadar Sibutramin Hidroklorida yang terkandung dalam produk herbal pelangsing yang tersebar di Banjarmasin. Metode yang digunakan untuk analisis kualitatif yaitu dengan kromatografi lapis tipis dan untuk analisis kuantitatif menggunakan metode spektrofotometri UV-Vis. Metode spektrofotometri UVVis divalidasi terlebih dahulu dengan parameter linearitas, LoD, LoQ, presisi dan akurasi. Hasil uji kualitatif dengan kromatografi lapis tipis pada 15 sampel tidak teridentifikasi mengandung Sibutramin Hidroklorida, sedangkan pada uji kuantitatif dengan metode Spektrofotometri UV-Vis 3 sampel teridentifikasi Sibutramin Hidroklorida yaitu pada sampel J, K dan $\mathrm{M}$ dengan kadar 5,8278\%, 8,5351\% dan 8,9342\%. Di Banjarmasin masih terdapat produk herbal pelangsing yang mengandung Sibutramin Hidroklorida.
\end{abstract}

Kata kunci : Sibutramin Hidroklorida, Spektrofotometri UV-Vis, Produk herbal pelangsing

\begin{abstract}
Herbal products prohibited of containing medicinal chemicals. In some studies, Medicinal chemicals included in herbal products. Sibutramine Hydrochloride is the most widely identified therapeutic chemical in herbal slimming products. The purpose of this study was to determine the content and levels of Sibutramine Hydrochloride contained in slimming herbal products spread in Banjarmasin. The method used for qualitative analysis is thin layer chromatography, and for quantitative analysis is using UV-Vis spectrophotometry method. The UV-Vis spectrophotometry method was validated first with linearity, LoD, LoQ, precision, and accuracy parameters. The qualitative test results did not identify sibutramine hydrochloride with thin-layer chromatography on 15 samples. However, the quantitative test using the UV-Vis Spectrophotometry method identified three samples as Sibutramine Hydrochloride, namely in samples $\mathrm{J}, \mathrm{K}$, and $\mathrm{M}$ with levels of $5.8278 \%, 8.5351 \%$, and $8.9342 \%$. In Banjarmasin, there are still herbal slimming products containing Sibutramine Hydrochloride.
\end{abstract}


Keywords: Sibutramine Hydrochloride, UV-Vis spectrophotometry, Slimming Herbs Product

\author{
Penulis Korespondensi : \\ Nadya Novani \\ Universitas Muhammadiyah Banjarmasin \\ Jl. Gubernur Sarkawi, Handil Bakti, Kalimantan Selatan \\ Email : nadyanovani999@gmail.com
}

\title{
PENDAHULUAN
}

Obesitas adalah masalah kesehatan yang terjadi di seluruh dunia, menurut data WHO pada tahun 2014 prevalensi obesitas mencapai lebih dari 1,9 miliar pada orang berumur ( $>18$ tahun) (Kementerian Kesehatan RI, 2018). Angka kejadian obesitas di Indonesia cenderung meningkat pada data tahun 2007, 2013 dan 2018 (Kementerian Kesehatan RI, 2018). Obesitas merupakan gangguan kesehatan fisik yang dapat memberikan dampak negatif terhadap kesehatan mental.

Obesitas bukanlah penyakit mental, tetapi dampaknya terkait dengan sejumlah masalah kesehatan mental. Stigma masyarakat bahwa penampilan yang menarik adalah terlihat dari tubuh yang langsing, hal ini dapat mengakibatkan penderita obesitas berusaha mencari cara untuk mengendalikan berat badannya dengan cepat. Keinginan untuk mengendalikan bobot tubuh dengan cara yang mudah dan cepat, mengakibatkan semakin banyak orang beralih ke berbagai produk pelangsing yang terbuat dari bahan alami. Produk pelangsing dari bahan alami dianggap tidak berbahaya, mudah di jual belikan karena tersedia tanpa resep dan sering kali harganya murah (Tang, et al., 2011). Pertimbangan untuk mengkonsumsi produk herbal adalah karena dianggap tidak memiliki efek samping bagi kesehatan dan aman dikonsumsi dalam waktu jangka panjang.

Produk herbal yang didalam ditambahkan bahan kimia obat dilarang di Indonesia (Permenkes RI No.007, 2012). Di beberapa negara tidak terkecuali di Indonesia, bahan kimia obat (BKO) terkandung dalam produk herbal untuk pelangsing. Dari beberapa zat terlarang yang sering teridentifikasi di dalam produk herbal pelangsing adalah Sibutramin, yang terdapat sekitar $73 \%$ produk herbal pelangsing yang mengandung Sibutramin (Tang, et al., 2011).

Sibutramin Hidroklorida memiliki mekanisme kerja yaitu dengan menghambat reuptake norepinefrin, serotonin dan dopamin oleh sel saraf setelah kedua neurotransmiter ini menyampaikan pesan diantara sel saraf yang ada di otak. Proses penghambatan reuptake membuat kedua neurotransmitter ini bebas menjelajah di otak, saat itulah keduanya menghasilkan perasaan penuh (kenyang) pada pasien sehingga mengurangi keinginan untuk makan (Tjah, 2007; Mahmudah, 2012). Sibutramine Hidroklorida jika digunakan dengan dosis tinggi dapat menyebabkan resiko meningkatnya tekanan darah, meningkatnya denyut jantung dan kesulitan tidur (BPOM., 2006; Sylvia, et al., 2018). Sibutramin klorida memiliki senyawa turunan berupa benzene klorida. Senyawa ini memiliki gugus kromofor yang dapat menyerap radiasi dalam daerah UV yaitu 200-400 nm, sehingga senyawa organik ini dengan konsentrasi yang rendah dapat terdeteksi Spektrofotometri UV-Vis. 


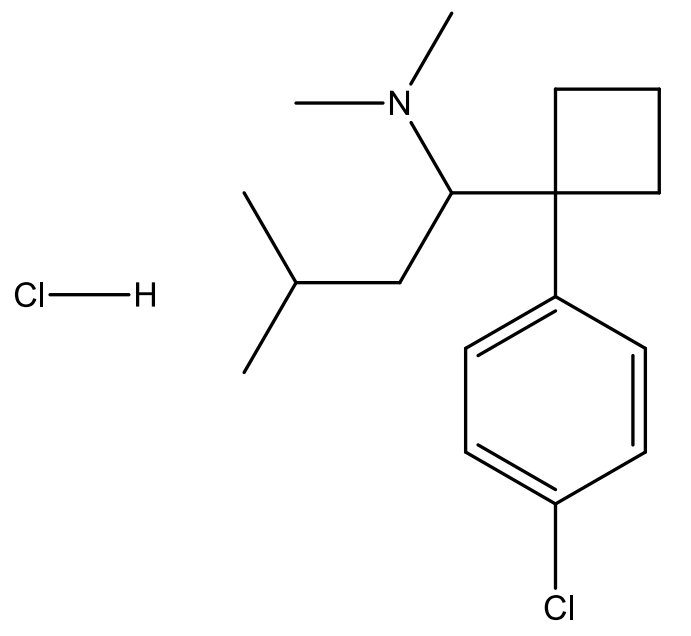

Gambar 1. Struktur Sibutramin Hidroklorida

Penemuan BKO pada produk pelangsing terjadi di beberapa wilayah Indonesia termasuk daerah Kalimantan Selatan. Banjarmasin merupakan salah satu kota di Kalimantan Selatan, di kota tersebut masih ditemukan peredaran produk herbal pelangsing yang mengandung BKO salah satu zatnya yaitu Sibutramin Hidroklorida. Pengujian secara kualitatif pada produk herbal tahun 2016, ditemukan 6 produk yang mengandung Sibutramin Hidroklorida di Kecamatan Banjamasin Tengah (Putra, 2016), maka tujuan dari penelitian ini untuk mengetahui kandungan dan kadar Sibutramin Hidroklorida pada produk herbal pelangsing yang tersebar di Banjarmasin.

\section{METODE PENELITIAN}

Jenis penelitian yang digunakan merupakan eksperimental. Teknik pengambilan sampel yang dilakukan adalah non-random dengan metode purposive sampling. Pengambilan sampel diawali dengan melakukan observasi di lima pasar yang mewakili 5 kecamatan di Banjarmasin dengam total 10 sampel yaitu di Pasar Cemara, Pasar Pekauman, Pasar Talawang, Pasar Kuripan dan Pasar Sentral Antasari. Pengambilan sampel juga dilakukan secara online dengan total 5 sampel online. Pengambilan sampel pada penelitian ini berdasarkan produk herbal yang berindikasi sebagai pelangsing, penjual berada di Banjarmasin dan produk yang paling diminati.

\section{Alat dan Bahan}

Spektrofotometer UV-Vis (Genesys), Mikropipet (Dragon Onemed®), gelas ukur (pyrex®), pipet volume, labu ukur (pyrex $\left.{ }^{\circledR}\right)$, pipet volume (pyrex $\left.{ }^{\circledR}\right)$, neraca analitik, kuvet, chamber (Camag), plat silika GF254 (Merck®), pipa kapiler, kertas saring, mortir dan stemper. Sibutramin Hidroklorida BPFI, 15 sampel produk herbal pelangsing Metanol pro analisis (Merck®), Aqua bidestilata, N-heksan pro analisis (Merck®), Kloroform pro analisis (Merck®), Aseton pro analisis (Merck®).

\section{Jalannya Penelitian}

1. Uji kualitatif, pembuatan larutan standar

Larutan dibuat dengan kandungan Sibutramin Hidroklorida 500 ppm dengan ditimbang Sibutramin Hidroklorida sebanyak $5 \mathrm{mg}$ dimasukan ke dalam labu takar 10 $\mathrm{mL}$, dilarutkan dan kemudian diencerkan dengan metanol sampai tanda batas. Kemudian dibuat larutan $50 \mathrm{ppm}$ dengan dipipet $1 \mathrm{ml}$ dari larutan induk $500 \mathrm{ppm}$, kemudian dipindahkan ke labu takar $10 \mathrm{~mL}$ kemudian diencerkan sampai tanda batas (Suthar, et al., 2009).

2. Preparasi sampel KLT

Sampel yang masih berbentuk tablet atau pil dihaluskan kemudian sampel ditimbang $1 \mathrm{~g}$, dimasukan ke dalam tabung reaksi dilarutkan dalam $5 \mathrm{~mL}$ metanol, dikocok selama 
30 menit, kemudian disaring. Filtrat dimasukan dalam labu takar $10 \mathrm{~mL}$ dan ditambahkan metanol. Plat KLT ditotolkan dengan baku dan sampel dengan fase gerak Aseton:Kloroform:N-Heksan (5: 3: 2) (Simaremare, et al., 2018).

3. Uji kuantitatif, Pembuatan larutan standar kuantitatif

Larutan dibuat dengan kandungan Sirbutamin Hidroklorida 1000 ppm dengan Sibutramin Hidroklorida ditimbang sebanyak $10 \mathrm{mg}$ dan dimasukan ke dalam labu takar $10 \mathrm{~mL}$, dilarutkan kemudian diencerkan dengan aqua bidestilata sampai tanda batas (Wisnu, et al, 2017).

4. Penentuan panjang gelombang maksimum

Penentuan panjang gelombang maksimum digunakan larutan 15 ppm yaitu dengan cara $150 \mu \mathrm{L}$ dipipet dari larutan baku $1000 \mathrm{ppm}$ dan ditambahkan dengan aqua bidestilata sampai $10 \mathrm{~mL}$, dimasukan ke dalam kuvet kemudian dibaca untuk mencari $\lambda$ maksimum menggunakan spektrofotometri UV-Vis pada rentang panjang gelombang $200-400 \mathrm{~nm}$ (Wisnu, et al., 2017).

5. Operating time

Larutan standar Sibutramin Hidroklorida 1000 ppm dibuat larutan baku 15 ppm dengan cara $150 \mu \mathrm{L}$ dipipet kemudian dimasukan kedalam labu takar $10 \mathrm{ml}$ dan ditambahkan dengan aqua bidestillata sampai batas tanda. Kemudian larutan dikocok hingga homogen. Larutan dimasukkan ke dalam kuvet kemudian dibaca absorbansinya pada panjang gelombang maksimum sampai diperoleh absorbansi yang relatif konstan dengan rentang pembacaan 1 menit sekali selama 10 menit (Wisnu, et al., 2017).

6. Kurva baku

Dari larutan standar 1000 ppm dibuat seri konsentrasi 15 ppm; 17,5 ppm; 20 ppm; 22,5 ppm dan $25 \mathrm{ppm}$ kemudian dibaca pada alat spektrofotometer UV-Vis dengan panjang gelombang maksimum yang sudah didapatkan sebelumnya (Maluf, et al., 2007).

7. Linearitas

Dibuat seri konsentrasi 15 ppm; 17,5 ppm; 20 ppm; 22,5 ppm dan 25 ppm. Pada masing-masing konsentrasi dilakukan pengukuran ulang sebanyak 3 kali dari larutan standar $1000 \mathrm{ppm}$ berbeda, absorbansi dibaca dengan alat spektrofotometer UV-Vis. Dibuat kurva baku dan persamaan garis linear untuk uji kuantitatif dari sampel yang diduga mengandung Sibutramin Hidroklorida. Nilai absorbansi diplot dan dapat ditentukan koefisien korelasi untuk setiap kurva kalibrasi (Maluf, et al., 2007).

8. LoD \& LoQ

Larutan seri konsentrasi 15 ppm; 17,5 ppm; 20 ppm; 22,5 ppm dan 25 ppm, diukur absorbansinya pada panjang gelombang maksimum. LoD \& LoQ dihitung dengan metode kurva kalibrasi dengan persamaan.

$$
\mathrm{LoD}=\frac{3 \mathrm{Sy} / \mathrm{x}}{\mathrm{Sl}}
$$

LoD (Limit of Detection) atau batas deteksi merupakan jumlah terkecil dari analit yang terdapat di dalam sampel yang dapat dideteksi dan masih memberikan respon signifikan dibandingkan dengan blangko.

$$
\mathrm{LoQ}=\frac{10 \mathrm{Sy} / \mathrm{x}}{\mathrm{Sl}}
$$

LoQ (Limit of Quantification) atau batas kuantifikasi merupakan parameter pada analisis renik dan diartikan sebagai kuantitas terkecil analit dalam sampel yang masih dapat memenuhi kriteria ketelitian dan ketetapan.

9. Ketelitian (Presisi)

Digunakan dari larutan standar Sibutramin Hidroklorida 1000 ppm dipipet sebanyak $150 \mu \mathrm{L}$ dipipet kedalam labu ukur $10 \mathrm{ml}$ dan ditambahkan aqua bidestilata sampai tanda 
batas. Larutan dimasukan kedalam kuvet, kemudian dibaca absorbansinya pada panjang gelombang maksimum. Untuk uji ketelitian ini dilakukan dengan enam kali pengulangan. Hasil absorbasi pengulangan digunakan untuk menghitung konsentrasi rata-rata, standar deviasi (SD), koefisien partisi (KV) dan ketelitian alat (Wisnu, et al., 2017).

10.Ketepatan (Akurasi)

Sibutramin Hidroklorida sebanyak $10 \mathrm{mg}$ ditimbang secara duplo, masing-masing dimasukkan ke dalam labu ukur. Pada salah satu labu ukur ditambahkan 9 mL larutan standar Sibutramin Hidroklorida. Kedua sampel tersebut ditambahkan aqua bidestilata hingga volume $10 \mathrm{~mL}$. Dikocok hingga homogen kemudian dari masing-masing larutan tersebut diambil $150 \mu \mathrm{l}$ kemudian diencerkan dengan aqua bidestilata hingga volume tepat $10 \mathrm{~mL}$ lalu dibaca absorbansinya pada panjang gelombang maksimum dan operating time. Uji ketepatan dilakukan dengan penambahan larutan standar $10 \mathrm{mg} / 10 \mathrm{ml}$ dengan 6 kali pengulangan (Wisnu, et al., 2017). Dihitung recovery

Dimana :

$$
\% \text { Recovery }=\frac{(\mathrm{C} 1-\mathrm{C} 2)}{\mathrm{C} 3} \mathrm{X} 100
$$

$\mathrm{C} 1=$ Kadar dari analit campuran matriks dan tambahan analit

$\mathrm{C} 2=$ Kadar dari analit dalam matriks

C3 = Kadar dari analit yang sebenarnya

\section{Preparasi sampel}

Sampel sebanyak $200 \mathrm{mg}$ ditimbang untuk sampel yang diperkirakan sebelumnnya mengandung Sibutramin Hidroklorida, larutan dimasukkan ke dalam labu takar $25 \mathrm{~mL}$ dan aqua bidestila ditambahkan sampai batas tanda. Kemudian dikocok selama 30 menit dan saring. Setelah itu dipipet $250 \mu \mathrm{L}$ dimasukan ke dalam labu ukur $10 \mathrm{~mL}$ dan aqua bidestilata ditambahkan sampai batas tanda, sampel dimasukan ke dalam kuvet lalu dibaca menggunakan Spektrofotometer UV-Vis (Wisnu, et al., 2017).

\section{Analisis Data}

Analisis kualitatif

Metode KLT digunakan untuk analisis kualitatif dengan menggunakan fase diam silika gel $\mathrm{GF}_{254}$ dengan jarak pengembangan sebesar $8 \mathrm{~cm}$ dan fase gerak campuran. Data KLT diperoleh dengan menghitung $\mathrm{Rf}$ yang didapat.

$$
\mathrm{Rf}=\frac{\text { Jarak yang digerakan oleh senyawa }}{\text { Jarak yang digerakan pelarut }}
$$

Analisis kuantitatif

Larutan standar diukur kemudian diperoleh hasil panjang gelombang maksimum, persamaan kurva baku dan nilai R. Persamaan kurva baku digunakan untuk menghitung kadar Sibutramin Hidroklorida di dalam sampel yang telah diukur absorbansinya pada panjang gelombang maksimum.

Keterangan :

$$
y=b x+a
$$

a : Intersep (menunjukan kepekaan analisis terutama instrumen yang digunakan)

$\mathrm{b}$ : Nilai slope (kemiringan)

y : Respon Instrumen

$\mathrm{x}:$ Kadar analit 


\section{HASIL DAN PEMBAHASAN}

Analisis kualitatif baku Sibutramin Hidroklorida dan 15 sampel obat herbal pelangsing dengan menggunakan fase diam $\mathrm{GF}_{254}$, pemilihan fase diam $\mathrm{GF}_{254}$ dikarenakan analit Sibutramin Hidroklorida tidak berwarna sehingga diharapkan dari kemampuan silika gel ini yang dapat berflouresensi dengan baik pada panjang gelombang $254 \mathrm{~nm}$ (Oktaviantari, et al., 2019)

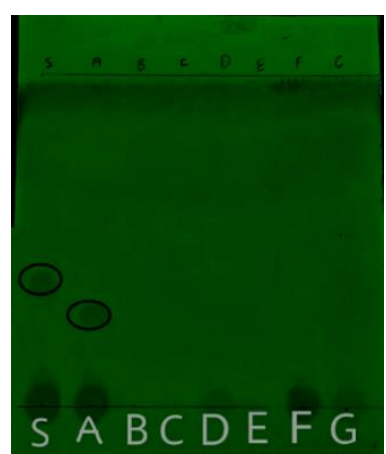

(a)

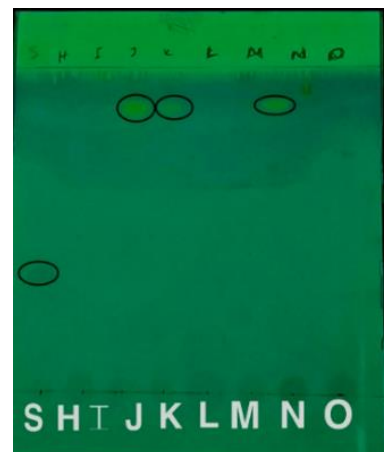

(c)

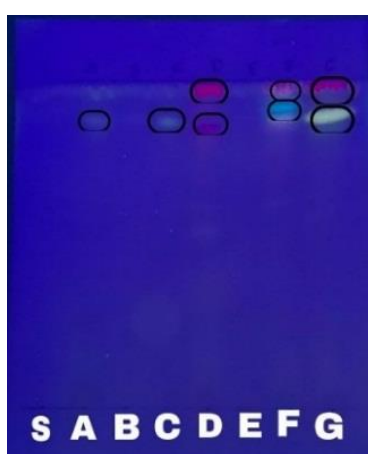

(b)

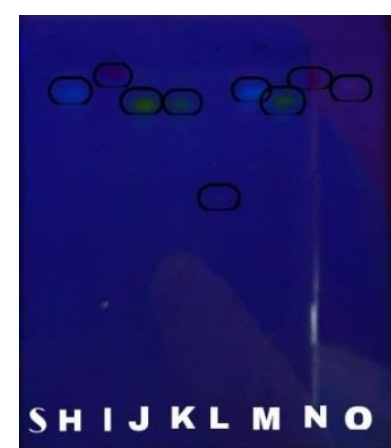

(d)

Gambar 2. (a) Sampel A-G pada $245 \mathrm{~nm}$, (b) Sampel A-G pada $366 \mathrm{~nm}$, (c) Sampel H-O pada $245 \mathrm{~nm}$ dan (d) Sampel H-O pada $366 \mathrm{~nm}$.

Tabel I. Hasil analisis kualitatif Sibutramin Hidroklorida pada sampel

\begin{tabular}{|c|c|c|c|c|c|c|c|}
\hline \multirow[t]{2}{*}{ No } & \multirow[t]{2}{*}{ Kode } & \multicolumn{2}{|c|}{ Hasil Pengukuran } & \multirow{2}{*}{$\begin{array}{l}\text { Jarak } \\
\text { Eluen } \\
(\mathrm{cm})\end{array}$} & \multicolumn{2}{|c|}{$\begin{array}{c}\text { Nilai Rf } \\
\text { (Jarak } \\
\text { Noda/Jarak } \\
\text { Eluen) } \\
\end{array}$} & \multirow[t]{2}{*}{ Kesimpulan } \\
\hline & & $\begin{array}{l}254 \mathrm{~nm} \\
(\mathrm{~cm})\end{array}$ & $\begin{array}{c}366 \\
\mathrm{~nm} \\
(\mathrm{~cm})\end{array}$ & & $\begin{array}{l}254 \\
\mathrm{~nm}\end{array}$ & $\begin{array}{l}366 \\
\mathrm{~nm}\end{array}$ & \\
\hline 1 & $S$ & 3,1 & - & 8 & 0.38 & - & Standar \\
\hline 2 & A & 2,1 & 7 & 8 & 0,26 & 0,87 & - \\
\hline 3 & B & - & - & 8 & - & - & - \\
\hline 4 & $\mathrm{C}$ & - & 7 & 8 & - & 0.87 & - \\
\hline 5 & $\mathrm{D}$ & - & $\begin{array}{c}6,9 ; 7 \\
, 8\end{array}$ & 8 & - & $\begin{array}{c}0,86 ; \\
0,97\end{array}$ & - \\
\hline 6 & $\mathrm{E}$ & - & - & 8 & - & - & - \\
\hline
\end{tabular}




\begin{tabular}{cccccccc}
7 & & & 6,$8 ;$ & & & 0,$85 ;$ & \\
& $\mathrm{F}$ & - & 7,1 & 8 & - & 0,$88 ;$ & - \\
8 & $\mathrm{G}$ & - & $7,4,9 ;$ & & & 0,92 & \\
& & & 7,9 & 8 & - & 0,$9 ;$ & - \\
9 & $\mathrm{H}$ & - & 7,2 & 8 & - & 0,9 & - \\
10 & $\mathrm{I}$ & - & 7,8 & 8 & - & 0,97 & - \\
11 & $\mathrm{~J}$ & 6,8 & 6,8 & 8 & $0,85:$ & 0,85 & - \\
12 & $\mathrm{~K}$ & 6,8 & 6,8 & 8 & 0,$85 ;$ & 0,85 & - \\
13 & $\mathrm{~L}$ & - & 4,2 & 8 & - & 0,52 & - \\
14 & $\mathrm{M}$ & 6,9 & $6,9:$ & 8 & 0,86 & 0,$86 ;$ & - \\
15 & $\mathrm{~N}$ & - & 7,2 & 8 & - & 0,$9 ;$ & - \\
16 & $\mathrm{O}$ & - & 7,5 & 8 & - & 0,93 & - \\
\hline
\end{tabular}

Noda yang dihasilkan dari 15 sampel produk juga diukur dan dihitung nilai Rf nya, kemudian dibandingkan dengan nilai Rf baku Sibutramin Hidroklorida. Ditemukan bahwa tidak terdapat sampel yang memiliki nilai Rf yang sama dengan baku pembanding Sibutramin Hidroklorida. Pada penelitian ini sampel yang muncul pada sinar UV $254 \mathrm{~nm}$ yaitu sampel A, J, K dan M. Nilai Rf sampel J, K, dan M hampir sama dengan sampel yang dinyatakan positif Sibutramin Hidroklorida dari penelitian (Putra, 2016) yaitu nilai Rf 0,94 karena sampel mengandung bahan lain yang dapat menyebabkan perbedaan Rf dibandingkan dengan Sibutramin Hidroklorida murni.

Sampel J, K dan M dilanjutkan pengujian secara kuantitatif dengan metode spektrofotometri UV-Vis, untuk memastikan bahwa benar tidak mengandung Sibutramin Hidroklorida. Penyebab sampel yang terdeteksi mengandung Sibutramin Hidroklorida dengan menggunakan spektrofotometer UV-Vis, tetapi tidak memiliki Rf yang sama dapat disebabkan karena pengotor yang terkandung dalam sampel (Putra, 2016), dalam studi stabilitas ditunjukan adanya degradasi dari produk herbal yang mengandung beberapa macam senyawa dan dapat mempengaruhi daerah serapan Sibutramin Hidroklorida (Maluf, et al., 2007). Sibutramin Hidroklorida dapat terdeteksi di spektrofotometer UV-Vis karena spektrofotometri memiliki sensitivitas lebih tinggi dibandingkan dengan metode kromatografi lapis tipis (Wisnu, et al., 2017).

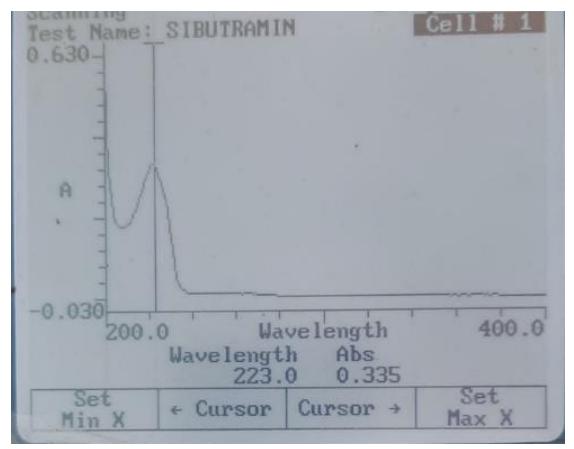

\section{Gambar 3. Panjang Gelombang Maksimum Sibutramin Hidroklorida}

Sibutramin Hidroklorida dengan konsentrasi 15 ppm memiliki absorbansi maksimum pada panjang gelombang $223 \mathrm{~nm}$ dengan absorbansi 0,335. Tujuan dari pengukuran panjang 
gelombang untuk mengetahui panjang gelombang yang dibutuhkan Sibutramin Hidroklorida mencapai absorbansi maksimum. Gugus benzen yang biasanya muncul pada panjang gelombang $200 \mathrm{~nm}$ tetapi pada Sibutramin Hidroklorida memiliki gugus benzen klorida yang disebut dengan pergeseran batokromik yaitu pergeseran absorban ke daerah Panjang gelombang yang lebih Panjang karena adanya efek pelarut atau substitusi gugus organik (Simaremare, et al., 2018).

Pengukuran operating time bertujuan untuk mengetahui lama waktu Sibutramin Hidroklorida untuk mencapai absorbansi konstan. Pengukuran operating time dengan konsentrasi dipilih 15 ppm menunjukan Sibutramin Hidroklorida konstan dari menit ke 1 sampai menit ke 10.

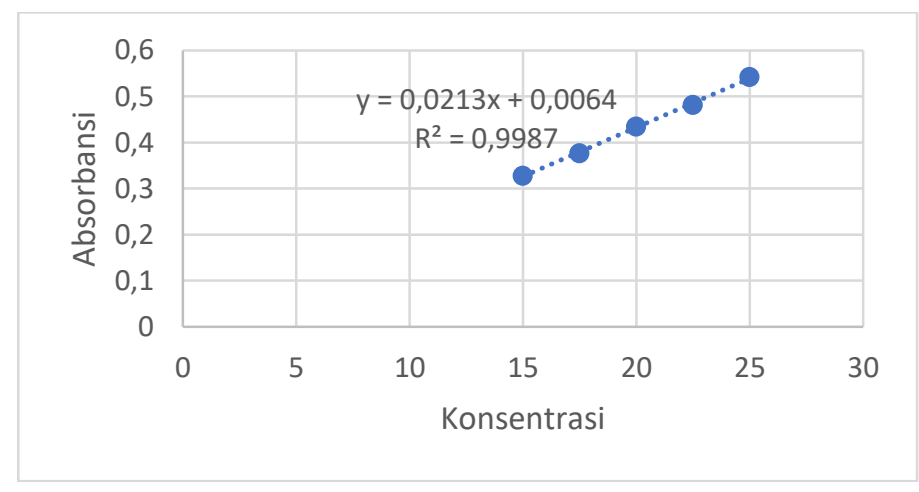

\section{Gambar 4. Hubungan konsentrasi Vs absorbansi}

Koefisien korelasi ditentukan dari nilai rata-rata 3 kurva. Berdasarkan hasil perhitungan didapatkan nilai koefisien determinasi $\left(\mathrm{R}^{2}\right)$ adalah 0,9987 , koefisien determinasi adalah indeks untuk mengetahui besarnya pengaruh variabel bebas terhadap variabel terikat. Syarat dari nilai koefisien determinasi adalah 0,997 (Chan, et al., 2005), artinya nilai koefisien determinasi pada penelitian ini memenuhi persyaratan. Kemudian koefisien korelasi yang digunakan untuk mengukur derajat hubungan berupa kekuatan hubungan dan arah hubungan, nilai koefisien korelasi ( $r$ ) yang diperoleh dari penelitian ini adalah 0,9993 . Nilai $r$ tersebut memenuhi persyaratan menurut (Ribani, et al., 2004) linearitas dengan nilai $r>0,999$ (Maluf, et al., 2007).

Data dari konsentrasi dan absorbansi rata-rata dihitung dan didapatkan nilai LoD adalah $0,505031 \mu \mathrm{g} / \mathrm{ml}$ dan nilai LoQ adalah $1,686769 \mu \mathrm{g} / \mathrm{ml}$. LoD adalah batas suatu alat dapat mendeteksi pada penelitian ini alat dapat mendeteksi pada konsentrasi terkecil 0,505031 $\mu \mathrm{g} / \mathrm{ml}$, respon deteksi ini menghasilkan nilai yang signifikan dibandingkan blanko (Riyanto, 2014). LoQ adalah batas terkecil suatu alat dapat mengkuantifikasi, pada penelitian ini konsentrasi terkecil yang dapat di kuantifikasi adalah $1,686769 \mu \mathrm{g} / \mathrm{ml}$. Konsentrasi yang didapat dari batas kuantifikasi dapat digunakan untuk menentukan presisi dan akurasi. Penentuan akurasi lebih baik diatas konsentrasi $1,686769 \mu \mathrm{g} / \mathrm{ml}$, jika dibawah batas kuantitasi atau LoQ berkemungkinan kurang akurat karena kemampuan nilai absorbansi sangat kecil (Riyanto, 2014). 
Tabel II. Data hasil presisi

\begin{tabular}{ccc}
\hline Data Pengulangan & Absorbansi & Konsentrasi \\
\hline 1 & 0,335 & 15,4272 \\
2 & 0,330 & 15,1924 \\
& 0,338 & 15,5680 \\
4 & 0,330 & 15,1924 \\
5 & 0,334 & 15,3802 \\
6 & 0,325 & 14,9577 \\
\hline \multicolumn{2}{c}{ RATA-RATA } & 15,0384 \\
\hline \multicolumn{2}{c}{ SD } & 0,2213 \\
\hline \multicolumn{2}{c}{ RSD (\%) } & 1,4719 \\
\hline
\end{tabular}

Pengukuran presisi dilakukan dengan repeatability, repeatability adalah metode penentuan presisi yang dilakukan secara berulang pada kondisi yang sama dan dengan jeda pengerjaan yang singkat (Hermita, 2004). Setelah diukur dan didapatkan nilai absorbansi, maka untuk mendapatkan konsentrasi digunakan kurva kalibrasi $y=0,0213 x+0,0064$. Dari hasil perhitungan RSD (\%) adalah 1,4719\%, jadi untuk nilai presisi alat yang diperoleh adalah 98,5281\%. Dimana nilai RSD sama dengan nilai KV, nilai RSD tersebut memenuhi persyaratan dan metode tersebut dapat memberikan presisi yang baik yaitu $\leq 2 \%$ (Riyanto, 2014).

Tabel III. Data hasil akurasi

\begin{tabular}{cccccc}
\hline Data & $\begin{array}{c}\text { Absorbansi } \\
\text { Awal }\end{array}$ & $\begin{array}{c}\text { Absorbansi } \\
\text { Setelah }+ \\
\text { Baku 9 mL }\end{array}$ & $\begin{array}{c}\text { Konsentrasi } \\
\text { Awal }\end{array}$ & $\begin{array}{c}\text { Konsentrasi } \\
\text { Setelah + } \\
\text { Baku 9 mL }\end{array}$ & $\begin{array}{c}\text { Persen } \\
\text { Recovery } \\
(\%)\end{array}$ \\
\hline 1 & 0,335 & 0,691 & 15,4272 & 32,1408 & 111,4240 \\
2 & 0,330 & 0,727 & 15,1924 & 33,8309 & 124,2566 \\
3 & 0,338 & 0,732 & 15,5680 & 34,0657 & 123,3180 \\
4 & 0,330 & 0,740 & 15,1924 & 34,4413 & 128,3260 \\
5 & 0,334 & 0,738 & 15,3801 & 34,3474 & 126,4486 \\
6 & 0,325 & 0,735 & 14,9577 & 34,2065 & 128,3253 \\
\hline \multicolumn{6}{c}{ RATA-RATA } \\
\hline
\end{tabular}

Ketepatan diukur dengan absorbansi awal dan absorbansi setelah penambahan baku $9 \mathrm{~mL}$. Ketepatan dinyatakan dalam persen perolehan kembali atau recovery. Konsentrasi didapatkan dari pengukuran absorbansi yang diolah dengan persamaan garis linier $\mathrm{y}=$ $0,0213 x+0,0064$. Hasil persen recovery rata-rata adalah $126,1349333 \%$, syarat akurasi yang baik adalah $80-110 \%$ (Hermita, 2004). Akurasi dan presisi dapat menentukan total kesalahan analisis, akurasi merupakan ukuran selisih antara harapan hasil uji dengan nilai referensi yang diterima karena metode dan kesalahan laboratorium (Riyanto, 2014).

Data akurasi dan presisi dapat dipengaruhi beberapa faktor yaitu dari pemilihan metode uji, kompetensi personil dan kalibrasi alat laboratorium (Ulfiati, et al., 2017). Pada penelitian sebelumnya dengan metode uji yang sama, akurasi yang dinyatakan sebagai nilai recovery memenuhi persyaratan yaitu 102,2 \% (Maluf, et al., 2007) dan 84,798 \% (Wisnu, et al., 2017). Hasil recovery dapat dinyatakan sebagai indikasi bahwa suatu metode akurat tetapi tidak lebih dari sekedar indikasi (Chan, et al., 2005). 
Tabel IV. Data hasil uji kadar sampel

\begin{tabular}{|c|c|c|c|c|c|c|}
\hline $\begin{array}{l}\text { Sampe } \\
1\end{array}$ & $\begin{array}{l}\text { Replikas } \\
\text { i }\end{array}$ & $\begin{array}{c}\text { Absorbans } \\
\text { i }\end{array}$ & $\begin{array}{c}\text { Konsentras } \\
\text { i } \\
(\mathrm{ppm})\end{array}$ & $\begin{array}{c}\text { Kadar } \\
(\mathrm{mg} / 20 \\
0 \mathrm{mg} \\
\text { sampel })\end{array}$ & $\begin{array}{c}\text { Kadar } \\
(\%)\end{array}$ & $\begin{array}{c}\text { Kadar } \\
\text { rata-rata } \\
(\%)\end{array}$ \\
\hline \multirow{3}{*}{$\mathrm{J}$} & 1 & 0,255 & 11,6713 & 11,6713 & $\begin{array}{c}5,835 \\
6\end{array}$ & \multirow{3}{*}{$\begin{array}{c}5,8278 \\
\%\end{array}$} \\
\hline & 2 & 0,244 & 11,1549 & 11,1549 & $\begin{array}{c}5,577 \\
4\end{array}$ & \\
\hline & 3 & 0,265 & 12,1408 & 12,1408 & $\begin{array}{c}6,070 \\
4\end{array}$ & \\
\hline \multirow{3}{*}{ K } & 1 & 0,358 & 16,5070 & 16,5070 & $\begin{array}{c}8,253 \\
5\end{array}$ & \multirow{3}{*}{$\begin{array}{c}8,5351 \\
\%\end{array}$} \\
\hline & 2 & 0,364 & 16,7887 & 16,7887 & $\begin{array}{c}8,394 \\
3\end{array}$ & \\
\hline & 3 & 0,386 & 17,8215 & 17,8215 & $\begin{array}{c}8,910 \\
7\end{array}$ & \\
\hline \multirow{3}{*}{$\mathrm{M}$} & 1 & 0,388 & 17,9154 & 17,9154 & $\begin{array}{c}8,957 \\
7\end{array}$ & \multirow{3}{*}{$\begin{array}{c}8,9342 \\
\%\end{array}$} \\
\hline & 2 & 0,385 & 17,7746 & 17,7746 & $\begin{array}{c}8,887 \\
3\end{array}$ & \\
\hline & 3 & 0,388 & 17,9154 & 17,9154 & $\begin{array}{c}8,957 \\
7\end{array}$ & \\
\hline
\end{tabular}

Dosis maksimal penggunaan Sibutramin Hidroklorida dalam satu hari adalah 15 mg (FDA, 2006;Putra, 2016). Sampel K dan M menunjukan kadar Sibutramin Hidroklorida melebihi dosis $15 \mathrm{mg}$, sedangkan sampel J menunjukan kadar Sibutamin Hidroklorida dibawah dosis $15 \mathrm{mg}$. Penggunaan bahan kimia obat di dalam produk herbal dilarang di Indonesia (Permenkes RI No.007, 2012), sehingga produk herbal pelangsing dengan kode J, K dan M sebaiknya dilakukan pemantauan lebih lanjut.

Hasil penelitian ini sejalan dengan penelitian sebelumnya dari Wisnu pada tahun 2017 yang menunjukan sampel produk herbal pelangsing mengandung Sibutramin Hidroklorida dengan konsentrasi rata-rata sebesar 1,772 \% hingga 9,759\% dalam sampel. Penemuan tersebut membuktikan bahwa masih terdapat beberapa produk herbal pelangsing yang mengandung Sibutramin Hidroklorida meskipun penggunaannya telah dilarang. Hasil penelitian ini menunjukan bahwa masih ada produsen yang menambahkan bahan kimia obat (BKO) Sibutramin Hidroklorida pada produk herbal pelangsing. 


\section{KESIMPULAN}

Hasil dari pengujian secara kualitatif menggunakan kromatografi lapis tipis (KLT) menunjukan dari 15 sampel tidak ada yang memiliki kesamaan nilai Rf dari baku Sibutramin Hidroklorida yaitu 0,38. Tetapi pada hasil kualitatif terdapat 3 sampel yaitu J, K dan M yang mempunyai Rf sama yang berturut $0.85,0.85$ dan 0.86 , kemudian untuk memastikan bahwa sampel J, K dan M benar tidak mengandung Sibutamin Hidroklorida dilanjutkan dengan uji kuantitatif. Kadar Sibutramin Hidroklorida pada sampel J, K dan M adalah 5,8278\%, $8,5351 \%$ dan $8,9342 \%$.

\section{DAFTAR PUSTAKA}

Badan Pengawas Obat dan Makanan Republik Indonesia. 2017. Peraturan Badan pengawas obat dan makanan Nomor 29 Tahun 2017.

BPOM. 2019. Peraturan Badan Pengawas Obat dan Makanan Nomor 32 Tahun 2019 Tentang Persyaratan Keamanan dan Mutu Obat Tradisional.

Chan, C. C., Lee, Y. C., Lam, H., \& Zhang, X.-M. 2005. Analytical Method Validation and Instrument Performance Verification. New Jersey: A John Wiley \& Sons, INC., Publication.

Hermita. 2004. Petunjuk Pelaksanaan Validasi Metode dan Cara Perhitungannya. Majalah Ilmu Kefarmasian, Vol 1 (3), 117-135.

Kementerian Kesehatan RI. 2018. Hasil Utama Riskesdas 2018.

Mahmudah. 2012. Identifikasi Sirbutamin HCl Pada Jamu Antiobesitas Yang beredar di Masyarakat Dengan Metode KCKT. Karya Tulis Starta Satu, Universitas Islam Negeri Syarif Hidayatullah, Jakarta.

Maluf, D.F., et. al, 2007, Validation of an Analytical Method for Determination of Sibutramine Hydrochloride Monohydrate in Capsules by Uv - Vis Spectrophotometry, Latin American Journal of Pharmacy, 26 (6): 909-12.

Oktaviantari, D. E., Feladita, N., \& Agustin, R. 2019. Identifikasi Hidrokuinon Dalam Sabun Pemutih Pembersih Wajah Pada Tiga Klinik Kecantikan Di Bandar Lampung Dengan Metode Kromatpgrafi Lapis Tipis Dan Spektrofotometri UV-Vis. Jurnal Analis Farmasi, 4(2), 91-97.

Permenkes R.I. No. 007/Menkes/VII/2012. Tentang Registrasi Obat Tradisional. Depkes R.I. Jakarta.

Putra, A. M. P. 2016. Qualitative Analysis Of Sibutramin Hydrochloride On Slimming Herbal Medicines Sold At Central Banjarmasin Areas. 1(1), 36-41.

Rand, K., Vallis, M., Aston, M., Price, S., Piccinini-, H., Rehman, L., ... Piccinini-, H. 2017. A multilevel analysis of psychological, emotional, and social well-being in obesity. International Journal of Qualitative Studies on Health and Well-Being, 12(1), 0-14. https://doi.org/10.1080/17482631.2017.1306421

Riyanto. 2014. Validasi \& Verifikasi Metode Uji Sesuai dengan ISO/IEC 17025 Laboratorium Pengujian dan Kalibrasi. Yogyakarta: Deepublish.

Simaremare, E. S., Susilowati, R. A., Astuti, Y. D., Hermawan, R., Gunawan, E., \& Pratiwi, R. D. 2018. Analysis of acetaminophen, mefenamic acid, sibutramine hydrochloride and sildenafil citrate. 8(2), 48-56. https://doi.org/10.7324/JAPS.2018.81107

Suthar, A.P., Dubey, S.A. \& Patel S.R., 2009, A Validated Spesific Reverse Phase Liquid Chromatographic Method for The Estimation of Sibutramine Hydrochloride Monohydrate in Bulk Drug and Capsule Dosage Forms, International Journal of Chemtech Research, 1: 793-801.

Tang, M. H. Y., Chen, S. P. L., Ng, S. W., Chan, A. Y. W., \& Mak, T. W. L. 2011. Case series on a diversity of illicit weight-reducing agents: from the well known to the unexpected._https://doi.org/10.1111/j.1365-2125.2010.03822.

Ulfiati, R., Purnami, T., \& Karina R. N. 2017. Faktor Yang Mempengaruhi Presisi Dan Akurasi Data Hasil Uji Dalam Menentukan Kompetensi Laboratorium. Lembaran Publikasi Minyak dan Gas Bumi. 665 LPMGB 51 (1) 2017. 
Wisnu, A. H., Sudewi, S., \& Lolo, W. A. 2017. Pelangsing Yang Beredar Di Kota Manado. $6(4), 75-81$. 